\title{
IMPACT OF CLAW DISORDERS IN DAIRY CATTLE ON HEALTH, PRODUCTION AND ECONOMICS AND PRACTICABLE PREVENTIVE METHODS
}

\author{
Petra Neirurerová1 ${ }^{1}$ Peter Strapákํㅗ Eva Strapáková2, Peter Juhás ${ }^{1}$ \\ ${ }^{1}$ Department of Animal Husbandry, Slovak University of Agriculture in Nitra, Trieda Andreja Hlinku 2, 94976 \\ Nitra, Slovak Republic \\ ${ }^{2}$ Department of Genetics and Animal Breeding Biology, Slovak University of Agriculture in Nitra, Trieda Andreja \\ Hlinku 2, 94976 Nitra, Slovak Republic
}

Link to this article: https://doi.org/10.11118/actaun.2021.038

Received: 2. 4. 2021, Accepted: 19. 5. 2021

To cite this article: NEIRUREROVÁ PETRA, STRAPÁK PETER, STRAPÁKOVÁ EVA, JUHÁS PETER. 2021. Impact of Claw Disorders in Dairy Cattle on Health, Production and Economics and Practicable Preventive Methods. Acta Universitatis Agriculturae et Silviculturae Mendelianae Brunensis, 69(3): 429-442.

\begin{abstract}
Problems with claw disorders in dairy cattle herds are very typical and are among the most significant endemic cattle diseases. It is good to realize in what condition we keep the cattle - unsuitable floors and bed boxes, greasy microclimate, frequent movement between groups of animals, significant changes in the feed ration - all this affects the health of claws. Lameness and claw lesions have a great impact on production, welfare and health of dairy cows. They decreases milk yield, have a negative impact on reproductive traits and fertility performance and therefore lameness increases costs including medicine, detection of lameness, control and prevention, and creates losses including reduced milk production, non-sellable milk, reduced reproductive performance, increased culling and animal death. To reduce the effect of claw disorders on dairy cattle, it is necessary to apply the most efficient combination of available methods of prevention. The most effective is the combination of early detection and diagnosis, regular claw trimming, proper diet and clean and suitable enviroment. The aim of this review was to cumulate the existing informations of aspects of claw lessions and known preventive methods for breeders of dairy herds.
\end{abstract}

Keywords: claw disorders, dairy cattle, hoof health, lameness, claw welfare, animal health economics

\section{INTRODUCTION}

Dairy cow lameness and related claw disorders are among the most notable issues concerning dairy herds worldwide. These diseases are as difficult to relieve as they are widespread in scope. According to Hulsen (2013), 75\% of all cows in Europe suffer from some form of claw disorder. Green et al. (2002) specifically state, that $70 \%$ of all dairy cows in UK had suffered a claw disorder of some sort at least once in their lifetime, same as 40 to $81 \%$ of cows in the study of Somers et al. (2003). These numbers indicate, that this problem affects all dairy farms globally. The subclinical nature of most of the claw disorders affecting dairy cows and the farmers inclination towards underestimation of the severity of these issues means, that they are easily overlooked or unassociated with cow lameness and that might be the root-cause of such statistics (Tadich et al., 2010; Alvergnas et al., 2019).

The importance of addressing the negative effect of claw disorders in dairy cattle has led to a higher interest in improving welfare for farm animals. Many known, and unknown factors affect claw disorder prevalence. Among the known ones are the environment, in which the cows live, the cows breed, how the cows are managed, even the cows genetic pedigree (van der Waaij et al., 2005; van der Linde et al., 2010; van der Spek et al., 2013; 
van der Spek, 2015). The cause of this is that claw disorders are affected by a multitude of factors and many other factors remain yet unknown (Somers et al., 2003; Ward, 2009; Bruijnis et al., 2011). Given the unpredictable nature of claw disorders, it is vital, that farmers ensure optimal environmental conditions for their herds and preventative earlystage detection of disorder (Mülling et al., 2006).

\section{DIVISION OF CLAW DISORDERS}

Necessity to harmonize vast amounts of disorder and claw health data led to the creation of ICAR Claw Health Atlas (Egger-Danner et al., 2015), which provides high quality data on the subject matter of claw health and disorders, also allowing for comparisons of data between different countries. Two main groups of disorders documented in ICAR Claw Health Atlas are infectious and non-infectious disorders (based on cause).

As the name implies, the cause of infectious disorders are bacteria, viruses, microorganisms and parasites. The dominating infectious diseases are digital and interdigital dermatitis, which are caused by Treponema spp. and Dichelobacter nodosus (Moore et al., 2005).

Non-infectious claw disorders are defined as mechanical injuries, or non-infectious traumatic disorders. Most common are thin sole, interdigitalis hyperplasia, asymmetric claws, corkscrew claws and scissor claws. Moreover, claw disorders related to laminitis associated with metabolic diseases belong to this category as well. Such disorders belonging to this category are concave dorsal wall, sole ulcer, double sole, sole hemorrhage, white line disease and horn fissure.

Interestingly, relation between individual disorders has been shown, as cows that had a disorder are more likely to have one again, particularly white line disease, sole ulcer, digital dermatitis and sole hemorrhage (Green et al., 2014).

\section{GENETIC PARAMETERS IN CLAW HEALTH}

When it comes to cow health issues, claw lesions are the third most impactful disorder, only surpassed by reproductive and mastitis disorders. Therefor genomic selection plays a vital role in improvements to claw health in the long run (Croué et al., 2019).

Establishing a routine recording of claw health data during claw trimmings on dairy farms proved beneficial in providing useful data for genetic evaluation (Heringstad et al., 2018).

To describe claw health, a range of sources of data and traits is available for use. Veterinarians can easily identify severe claw disorders, while data gained via locomotion and lameness scoring, records from sensors measuring activity and traits of feet and leg conformation are used as auxiliary traits. Nevertheless, the most genuine and broad data stems from hoof trimmings conducted on a regular basis. Claw disorders are mostly recorded as binary traits, when it comes to genetic evaluation. A cow either has a claw disorder, or it does not during the defined time period of evaluation. These traits can specify disorders, or composite traits. Validation of data together with editing criteria are used to secure data reliability on all data levels. Different countries adopted different ways of recording and processing data, these strategies often reflect differences in size of herd, structures of data, differences in management and differences in data recording systems (Koenig et al., 2005; Häggman et al., 2013; Van Pelt, 2015). Upon analysis of data gathered via routine claw trimmings, it was revealed, that heritability of the most common claw disorders was generally low. Linear models estimate a heritability ranging from 0.01 to 0.14 , threshold models estimate a range from 0.06 to 0.39 , with estimated genetic correlations of claw disorders being varied from 0.40 to 0.98 . White line disease, sole ulcer and sole hemorrhages were found to have the strongest genetic correlations. Other were found between heel horn erosion and digital dermatitis. Genetic correlation between these two groups was low in most cases. Even though some of the studies worked with small amounts of records, with estimated genetic parameters with large standard errors, with the exclusion of a few exceptions, most of the studies showed consistency among themselves (Aamand, 2006; Østerås et al., 2007; Egger-Danner et al., 2012). Various studies worked on evaluating the potential of using multiple data sources for use in breeding. Hoof trimming data use is recommended for maximizing genetic gain, while auxiliary trait data such as locomotion score may be of use by increasing the reliability of genetic evaluations. Use of routine genetic evaluations of the claws has already been implemented in countries like the Netherlands, Sweden, Norway and Finland, with other countries planning to do the same in the near future (Heringstad et al., 2018).

The Austrian dairy cattle breeding program "Klauen-Q-Wohl" only records foot and leg conformation, no lameness or locomotion data is being recorded so far. Other claw health traits require consideration, reveals a survey made among Austrian farmers (Steininger et al., 2012). To serve this purpose, the "Efficient Cow" project was initiated in Austria in 2012. Data was recorded on phenotypes, including lameness and data acquired via hoof trimming. These data were collected on 161 farms, totaling 6105 cows in Austria. The breeds covered by this data collection were Fleckvieh, Brown Swiss and Holstein.

Data from 6519 cows from 161 farms was analyzed by Köck et al. (2018) per the "Efficient Cow" project. Part of this project was assessing lameness scores during each milking recording period, which was done by trained staff. Claw trimming 
data, veterinarian diagnoses and culling due to hoof or limb problems was recorded and analyzed as part of the project as well. Availability of these data allowed for a general lactation lameness score calculation to be made.

The estimated heritabilities of lameness in 2014 were 0.11 for Fleckvieh, 0.05 for Brown Swiss and 0.09 for Holstein. Out of these, only Fleckviehs value was significantly different from zero. By obtaining breeding values for lameness, a cow ranking was devised, where cows were rated according to their breeding value. Cows with a low breeding value for lameness resistance, the bottom 10\% of the cows in question, were associated with a much higher frequency of trimmings; and inversely, the cows with a high breeding value for lameness resistance, the top $10 \%$ of cows were associated with a low frequency of claw diseases during claw trimmings, or culling due to leg diseases, underlining the significance and usefulness of lameness scoring for claw health. Improvements to lameness scoring and recording have much potential. They could lead to lower frequency of claw diseases, fewer of these diseases than becoming severe and much fewer culling due to lameness (Köck et al., 2018).

Health records are crucial for improvement of animal health via preventive measures, epidemiological research, genetics and environmental improvements (Heringstad and Østerås, 2013). The use of survey data still poses challenges, mostly in terms of data quality and application, where a deeper understanding for how to use that data is needed (Maltecca, 2013). Several analyses were performed to investigate disease data clustering at an individual level. In order to improve data quality, causes of incomplete data must be recognized. Many records in the dataset did not have complete observations for all the included health events (Maltecca et al., 2013; Emanuelson, 2013). The completeness is generally affected by age of the animal, disease complex, origin of the animal and the region. The completeness of the records in the database in Finland varied between 0.84 and 0.96 and in Norway between 0.97-9.98 (Emanuelson, 2013). In 2010 a survey based on 600 farms, which were excluded due to validation criteria, was carried out. The survey showed that despite promotion, not all farms or their veterinarians are providing reliable health data. The main reasons for incomplete data mentioned were missing documentation of treatments in general, missing standardization, or that not all available receipts were provided by the farmer (Egger-Danner et al., 2013). When working with data obtained from the field, divergence between real incidence of disease and observed and processed incidence must be considered. Depending on the management strategy implemented, not all data may be recorded properly, or recorded at all, making data validation a key issue in health monitoring systems (EggerDanner et al., 2013).

\section{PHYSIOLOGICAL REPERCUSSIONS OF CLAW DISORDERS}

\section{Health}

According to Gonzales et al. (2008), acute locomotion disorders, especially foot lesions, led to fewer and shorter feeding times, but with increased feeding rates. According to Bach et al. (2007), the amount of time a cow spends eating, and the number of times it feeds is lessened, depending on the cows locomotion score. The recorded time difference is 28 minutes between cows with a locomotion score of 1 and cows with a locomotion score of 5; together with fewer feeding times this results in a lower overall intake of dry matter, especially in cows that are the most lame. In another study, where 205 cows in 16 herds were observed, it was documented, that the increase of locomotion score caused a crucial reduction in the eating time of cows (Gomez and Cook, 2010).

In a study conducted in the US it was discovered, that the presence of lameness is much higher for cows with a lower body condition score than 2.5 including, when compared to cows which had their body condition score higher (Espejo et al., 2012). Furthermore, there have been found healthy cows with much higher body condition score, than were found in lame cows in five farms in Hungary (Gudaj et al., 2012) and on the farm in UK, a significant number of lame cows had a lower body condition score (Walker et al., 2008).

Several results confirm the negative effect of lameness on reproductive traits (Walker et al., 2008; Walker et al., 2010; Huxley, 2013; Burgstaller et al., 2017). Lameness can increase the time between calving and first service, conception and next calving, and can increase also the time between first service and conception; the measures of conception, the days open and the numbers of services per conception (Huxley, 2013).

Lame cows in the pre-service period had increased odds of a delayed cyclicity occurring (Garbarino et al., 2004), with a higher occurence of ovarian cysts occurring as well (Melendez et al., 2003). Such cows also received more hormonal reproductive treatment and had higher odds for receiving treatment for anestrus. These cows were also less likely to ovulate (Sogstad et al., 2007). The periods in which herd mates attempted to mount these cows were also much shorter (Walker et al., 2010), with estrus less likely observable. Lame cows had a much lower score of estrus intensity and a lesser recurrence of mounting activity (Walker et al., 2008). According to a study conducted by Sood and Nanda (2006), the frequency of mountings was a lot lower in lame animals i.e. 2.4 events vs 8.0 events.

\section{Production}

Among the most frequent physiological factors linked and affected by claw lessions is milk production. A cow's probability to become lame 
I: Reported milk loss $(\mathrm{kg})$

\begin{tabular}{l}
\hline Report milk loos (kg) \\
\hline 270-440 (Coulon et al., 1996) \\
314-424 (Bicalho et al., 2008) \\
350 (Archer et al., 2010b) \\
357 (Green et al., 2002) \\
369 (Amory et al., 2008) \\
372 (Gudaj et al., 2012) \\
574 (Amory et al., 2008) \\
857 (Hernandez et al., 2002) \\
\hline Source: Huxley, 2013
\end{tabular}

became 1.06 times higher with every $100 \mathrm{~kg}$ of milk produced during her lactation. These data were gained by direct comparison to the Dutch Holstein population (Barkema et al., 1994). Additionally, several other studies showed the expected drop in milk yield production by dairy cows suffering from claw disorders (showed in Tab. I).

In studies conducted in the field of cow lameness impacts, production losses have been documented with both mixed causes and specific lesion related cases. Among the specific cases were mainly sole ulcers, digital dermatitis, interdigital dermatitis, double soles and white line diseases. Cows which were identified by locomotion score as lame, using a variety of scoring systems and not excluding animals tagged as lame and not yet treated, have also demonstrated losses. Some studies suggest, that the decrease of production starts even before any lameness is identified. Weeks, even months may pass in some cases, before such lameness is identified (Huxley, 2013).

\section{Culling}

According to Machado et al. (2010), cows which suffered from horn lesions were more probable to by culled by 1.7 times. Along with the majority of works published in this field, the association can be made, that cows suffering from lameness are more probable to be culled or to die.

According to McConnel et al. (2008), farms with higher levels of lameness are more likely to have higher mortality. His results were acquired by examining data from 953 farms from around the world. In a different study, consisting of 6513 cows in 157 herds, the cows without any claw disorders had the median time for culling 188 days, while for the cows with claw disorders it was merely 157 days (Cramer et al., 2009).

\section{ECONOMIC IMPACT OF CLAW DISORDERS}

The economic impact of claw disorders on the dairy industry is undeniable. Only in terms of occurrence and cost, claw disorders place third, right after mastitis and reproductive disorders.
(Hernandez et al., 2002; Cha et al., 2010). According to Green et al. (2014), cow lameness leads to higher frequency of other disorders, such as metabolic issues, or lower fertility. Lowered body condition score or smaller milk yields are also tightly linked to cow lameness. Alvergnas et al. (2019) state, that the costs for lameness in cows range from $\$ 51.5$ to $\$ 1.517$ ( $\$ 31.5$ to $\$ 83$ per cow per year). Bruijnis et al. (2010) calculated those costs to be $\$ 160$ for IH and $\$ 1517$ for DD per year. The mean costs for the herd were \$4899 (\$75 per cow per year). Verhoef (2014) developed a model for farmers in the Netherlands to calculate the costs of claw disorders. The costs were calculated for DD, ID, IP, SU, WL, SH and $\mathrm{IH}$. The total cost was $3392 €(\approx 4678 \$$; i.e. 23 to $60 € \approx 31.5$ to $83 \$$ per cow per year) for a 77 dairy cows farm. Milk loss was the highest part, more than $33 \%$ of the total costs. According to Cha et al. (2010), these prices consists of the following: $40 \%$ of the costs are from milk losses, $34 \%$ of the costs are from treatment and $26 \%$ of the costs come from decreased fertility. The negative economic impact could be drastically reduced by increased awareness and farmer concern for cow claw health. The animals health and welfare would be thus improved as well (Bruijnis et al., 2013).

Automated detection of lame cows could provide useful information. Unfortunately, possible marginality of the returns, such an automated lameness detection would introduce mean, that the given benefits of such a system might not be enough. Economic loss stems only partly from inability to identify lameness. Even though the benefits of early claw disorder treatment are well documented, most farmers consider any claw disorder which is less than severe, to be non-urgent (Horseman et al., 2014). Even after identifying a cow as lame, several weeks may pass until treatment ensues in such cases (Alawneh et al., 2012; Leach et al., 2012).

Bruijnis et al. (2010) calculated the cost of some claw disorders for farm with 65 dairy cows. The cost was devided as follows: 44\% milk loss, $22 \%$ early culling, $12 \%$ additional work for the farmer and $12 \%$ increase of calving interval. The costs ranged from $147 €$ for interdigital hyperplasia to $1393 €$ for digital dermatitis per year. The mean costs for the herd were $4498 €$, ranged from $2954 €$ to $6428 €$, i.e. $69 €$ per cow per year, with $47 €$ for clinical disorders and $22 €$ for subclinical problems.

Charfeddine and Perez-Cabal (2017), calculated the costs for severe and mild lesions of dermatitis, sole ulcer and white line disease. These have been separated to direct (trimming, treatment, discarded milk and extra labor) and indirect (premature culling, additional days open and milk yield reduction). The magnitude of the indirect costs and their inpact on the total cost (43 to 60\%) was thoroughly propagated by the authors, who also emphasise the increased costs associated with severe lesions, ranging from 2.6 to 7.6 times the costs, when compared to mild lesions. 
In order to aid with making economically ideal decisions, Verhoef (2014) created a model for calculating the costs associated with claw disorders. Calculations were made for costs for digital and interdigital dermatitis, interdigital phlegmon, white line disease, sole ulcer and interdigital hyperplasia with clinical and subclinical statuses being distinquished. The total cost amounted to $3392 €$ (ranging from 23 to $60 €$ per cow per year) on a farm composed of 77 dairy cows, with a mean milk yield of $8218 \mathrm{~kg}$ in 305-day lactation. The highest recorded loss was due to milk loss, which amounted to more than 33\% of the total costs.

According to McInerney et al. (1992), the total cost of disease is defined by two governing factors - expenses and losses. Expenditures center on treatment of disease and providing future prevention, while losses are derived from disease manifestation causing a reduction in milk production, a reduction in reproductive performance and observable decline associated with other factors. Depending on the factors included in a total cost estimate of a study, different factors may be of different relative importance. To put matters into perspective: in a study, where the only included factors are treatment, milk production losses and reproductive performance losses, treatment expenditures may become the largest contributor of the total lameness cost; additionally, in a study with the additional inclusion of increased risk of culling, control and prevention investments, treatment will present a lesser percentage portion of the total cost.

In order to secure as accurate as possible calculations, the total costs of lameness should always contain multiple expenses and losses. This still requires additional research to accurately define, mainly in regard to particular types of lameness diseases, their gravity and the stage of lactation they occur in. Other herd specific and cow specific factors influence total lameness costs as well (Dolecheck and Bewley, 2018).

\section{EXTERNAL INFLUENCES ON CLAW HEALTH}

\section{Diagnosis}

Locomotion scoring of herds should be done at least monthly according to some recommendations (Horseman et al., 2014). Unfortunately, the regularity of locomotion scoring and/or routine hoof trimmings is much lower, even going as far as not occurring at all on some farms (Adams et al., 2017; Dolecheck and Bewley, 2018). Farmers are mostly satisfied with only ad hoc detection, contrary to what experts agree on (Horseman et al., 2014). Since ad hoc detection is inept at detecting mild to moderate lameness, assumptions can be made, that farmers are aware only of severe cases of lameness detected by ad hoc. Another downside of using only ad hoc detection is lack of herd statistics otherwise generated by routine hoof trimmings and locomotion scoring (Leach et al., 2012; Fabian et al., 2014; Sadiq et al., 2019).

Leach et al. (2012) mention the benefits that automated lameness detection would provide regarding mild and moderate lameness, which present a gap in lameness detection and identification. Early detection and treatment could prevent claw disorders from becoming severe, saving costs, speeding up recovery and treatment,

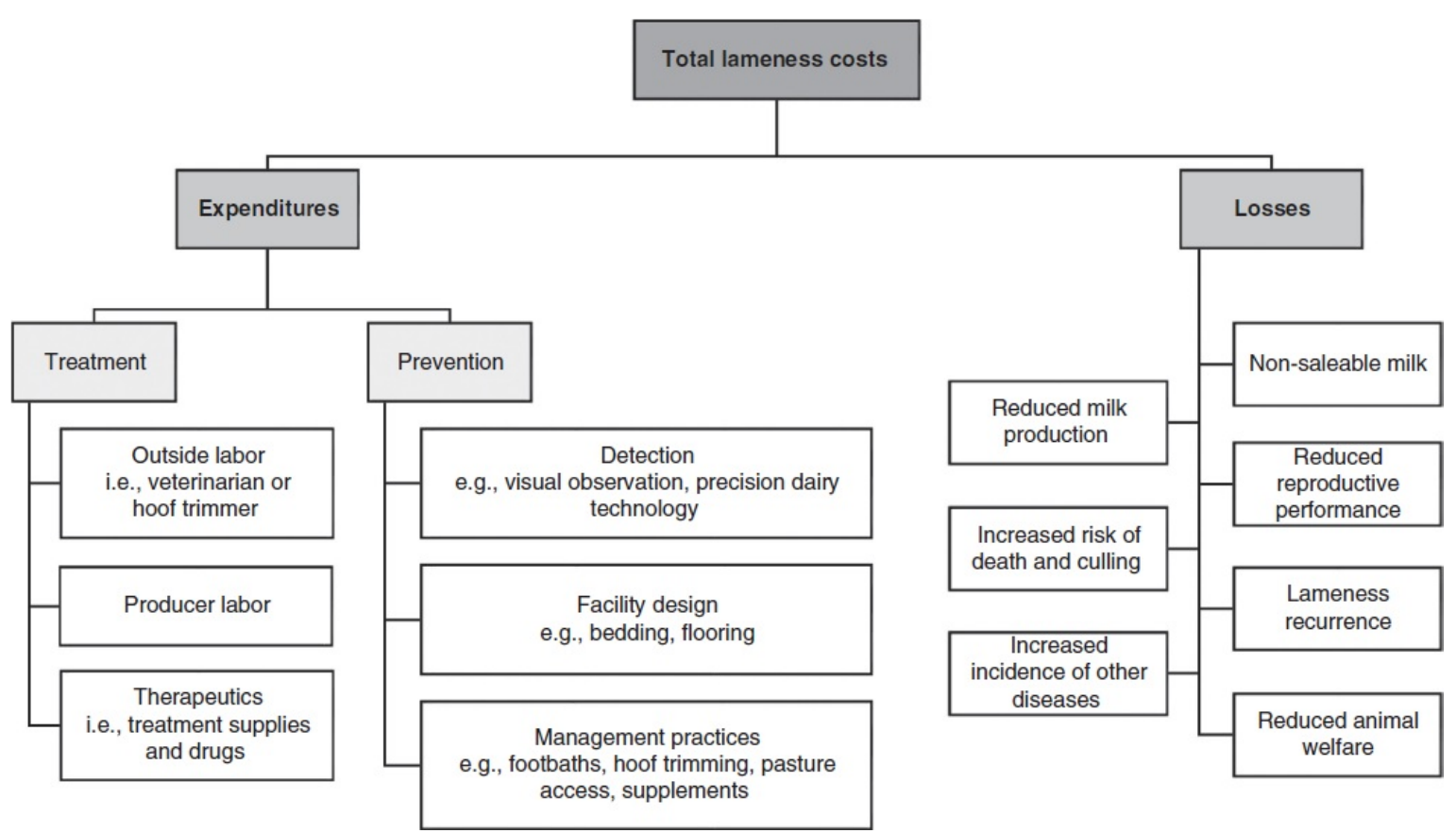

1: Total lameness costs (Dolecheck and Bewley, 2018) 
reducing losses from lowered production and improving welfare. If such a system would prove it-self, it could provide a positive feedback loop to the farmers, motivating them to invest more in preventative systems and focus more on reducing lameness in general (Horseman et al., 2014). Also, by introducing systematic recording of lameness, breeding for lameness resilience could be supported (Heringstad et al., 2018; Croué et al., 2019).

\section{Floor and Housing Conditions}

Low quality floors are one of the main factors behind claw lesions, mainly as white-line fissures, sole ulcers and sole haemorrhages; therefor proper floors are vital to the improvement of dairy cows claw health (Chesterton, 1989; Cook and Nordlund, 2009).

Hard floors like slatted concrete, or mastic asphalt result in application of high amounts of pressure on the bottom side of claws. This in turn can cause claw lesions (Van der Tol et al., 2002). Another downside of hard floors is their tendency to be excessively abrasiveness or slipperiness, adding to the presence of traumatic injuries and claw disorders (Webb and Nilsson, 1983). Farmers suggest, that rough mastic asphalt floors cause thinning of the claw sole, but these claims have hardly been investigated (Pahlke, 2004; Schneider, 2006). One main advantage of hard floors like slatted concrete, according to Thysen (1987) is the ease, by which manure is removed from them. The presence of Heel-horn erosion is much reduced by this advantage.

Improper floor surfaces, especially slippery surfaces are a major contributor towards the occurrence of white line disease, most commonly found in freestalled dairy herds. White line of the claw is the softest part of the claw, the strength of which is affected by the amount of keratinization of the claw. The process of keratinization is influenced by laminitis. Mechanical trauma has considerable impact on the white line, since it is situated between the horn of the wall and the softer horn of the sole (Endres, 2017).

Softer floors, like rubber floors placed in the walking areas of housings for dairy cows have been examined and compared to hard floors could provide an improved replacement. More studies on the subject reveal, that rubber slated floors and solid rubber floors lead to fewer claw lesion occurrences than (Benz, 2002; Vanegas et al., 2006; Bell and Huxley, 2009). Nevertheless, other sources indicate an insignificant impact when using soft floors made of rubber (Boyle et al., 2007; Kremer et al., 2007). Krebs et al. (2011) outright disputes any mitigation of claw lesions by rubber floors. Soft flooring might help by reducing pain and wear on claws, leading to lesser lameness in cow herds, but their installation in freestall barn alleys is recommended against. Such an installation coupled with uncomfortable stalls might lead to cows standing in the alleys, or outright laying in the alleys, reducing cow welfare and even reducing claw health as such behavior would allow for higher prevalence of infectious claw disorders like digital dermatitis.

According to Haskell et al. (2006) and HernandezMendo et al. (2007) pasturing has beneficial impact on claw health of cows housed in freestall barns. A study by Hernandez-Mendo et al. (2007) showed an positive progress in scores of locomotion, measured over a period of 4 weeks, by moving Holstein dairy cows from hard floor keepings to pastures, even though cows on pastures spent less time (1.4 hour difference per day) laying down than cows kept indoors. A study by Olmos et al. (2009) compared Holstein cows kept and housed on pastures with freestall housed cows from the $85^{\text {th }}$ day after calving until lactation ceased. Cows kept in pasture housings had less severe claw disorders, had better locomotions score and exhibited less clinical lameness unlike cows kept in barns. Cows kept on pastures also exhibited longer laying times which might lead to lesser incidents leading to lameness. In a study of barns using compost bedded packs, it was revealed, that cows during summer time had spent only 9.3 hours laying down per day. These cows were standing on the soft sawdust surfaces for the most of their time, rather than on hard flooring and still achieving a lameness prevalence of only $7.8 \%$. These studies point toward standing time being an issue especially in confinement facilities using hard concrete floors. Nevertheless, pasture housing tend to expose claws to a multitude of pathogens and other potentially dangerous conditions. New Zealand, with a mostly pasture oriented dairy industry shows a lameness incidence varying from 5 to 50\%. Even with these results, most research points toward confinementbased herds having much greater lameness prevalence and incidence (Bennett et al., 2009).

\section{Prevention}

Lameness, which is an abnormal gait, is an unwanted veterinary problem causing welfare issues on dairy farms, such as pain and debilitation. Its endemic nature is also an issue. Lameness in it-self is a response to pain which can originate in a multitude of pathologies (O'Callaghan, 2002; Van Nuffel et al., 2015; Alsaaod et al., 2019). Managing lameness is done through prevention and treatment. To prevent cow lameness, variables and factors associated with cow lameness must be attended to. These include, but are not limited to: nutrition, walking surfaces or flooring and genetics. Treatment on the other hand prerequisites identification of the cow as lame. This identification usually occurs in one of three ways. Firstly locomotion scoring systems, those asses herds systematically (Schlageter-Tello et al., 2014; Van Nuffel et al., 2015). Second, routine hoof trimmings by a specialist (Adams et al., 2017; Dolecheck and Bewley, 2018). Third and most common, ad hoc observations during other activities e.g. herding. 
Data gathering and recording is common practice in multiple fields on dairy farms, such as udder health, reproduction data etc. Unfortunately claw health data is rarely part of this practice. Different claw health documentation softwares have already been developed in Germany, UK, USA, Denmark and other countries. These programs allow for automatic detection of claw lesions presence, their location and severity and are gathering data of the prevalence of lameness (Kofler, 2013).

In recent years, several new programs from Europe and North America, focused on recording and processing claw related data were introduced, namely: KLP/KLP mobil, DLBR Klovregistrering, Klauenmanager, Digiklauw, Hooftec, I-SAP, Hoof Supervisor System, Pocket Trimmer System Dairy Comp 305, Accu-Trac Hoof Analyzer (Kofler, 2013).

Documenting and processing data related to claw health digitally would be very beneficial, leading to raised health standards in dairy herds, providing support and feedback to farmers, veterinarians and even claw trimmers. These benefits could be achieved worldwide, even in the next decade (Kofler, 2013).

\section{Trimming}

Hoof walls grow approximately 5 to $7 \mathrm{~mm}$ monthly, while sole growth is somewhat slower, approximately 3 to $4 \mathrm{~mm}$ monthly. Unless this growth is maintained via natural wear and/or trimming, overgrowth of the horn capsule ensues. This is especially true for animals held in tied captivity. Horn capsule overgrowth can then lead to incorrect weight bearing, which in turn can lead to formation of sole ulcers. Claw trimming is thus vital for the welfare of cows. Trimming prevents many claw related problems, such as hoof lesions and improves locomotion by maintaining the correct shape, size,

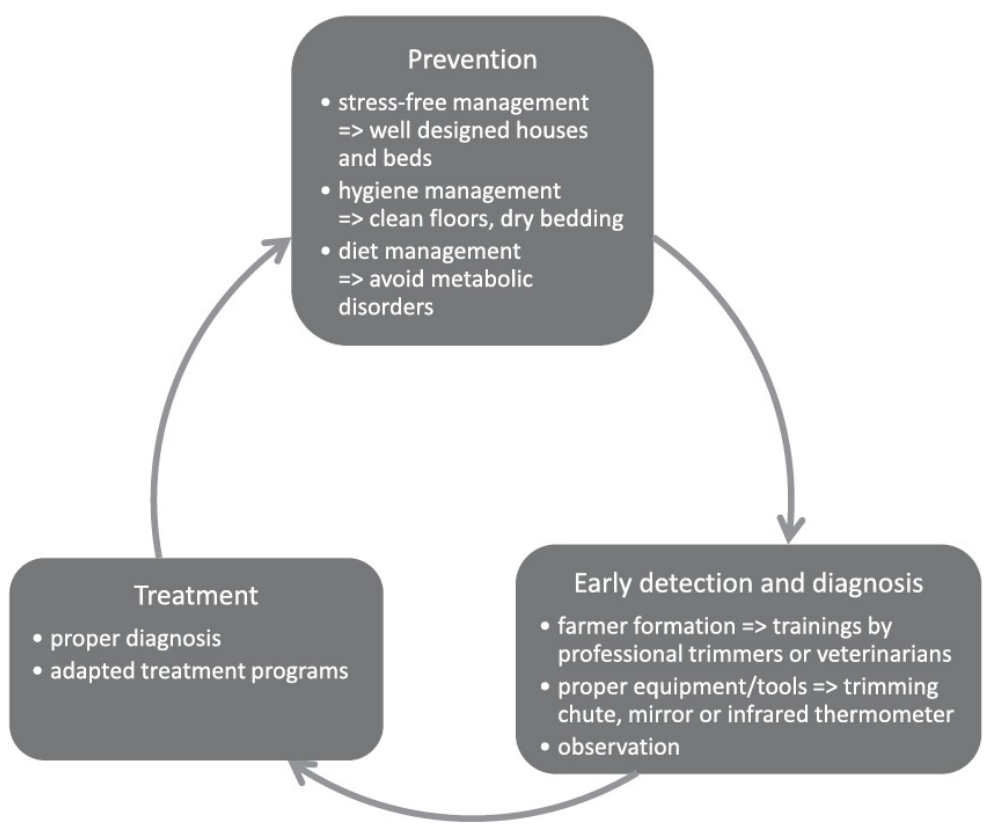

2: Claw disorder prevalence relative to their localization (Alvergnas et al., 2019)

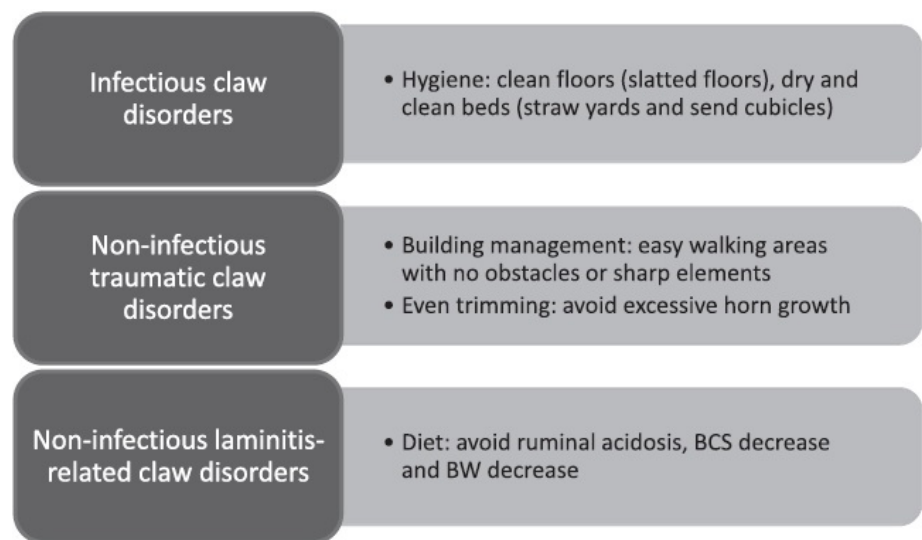

3: Best preventive methods of dealing claw disorders categorized by groups (Alvergnas et al., 2019) 
even symmetry of hooves. Maintaining claws in their nominal shape ensures retaining proper weight bearing (Manske et al., 2002).

Functional claw trimming has one main objective, to preserve proper weight bearing and functionality of each claw. Claw trimming has to be applied properly, in order to provide correction of hoof overgrowth. Hoof overgrowth can overburden affected claws, leading potentially to claw disorders. Correct application of claw trimming results in claws returning to their nominal shape, size and proportions, allowing normal foot function (Shearer and van Amstel, 2001).

The main purpose of foot trimming is the correction of hoof overgrowth and ensuring correct weight bearing individually and weight distribution between all four claws. Another advantage of timely feet trimming is the possibility of early detection and repair of claw disorders, preventing possible lameness (Fjeldaas et al., 2006).

Claw trimming is thus vital for the welfare of cows. Trimming prevents many claw related problems, such as hoof lesions and improves locomotion by maintaining the correct shape, size, even symmetry of hooves. Maintaining claws in their nominal shape ensures retaining proper weight bearing (Shearer and van Amstel, 2001).

Most cows benefit from one to two hoof trimmings annually, although cows that previously experienced either laminitis, or any other form of claw capsule related abnormality may require more than two trimmings yearly. Unfortunately, on most dairy farms cows claws are trimmed when the cows become lame, or during dry off, which is less than ideal, since most cows develop claw disorders in late lactation. On account of the effects that feeding, housing and laminitis have on hoof overgrowth, trimming could be done at mid-lactation, together with trimming at dry off, ensuring the optimal amount of two trimmings yearly (Shearer and van Amstel, 2001).

Claws that were trimmed in fall had lower occurrence of claw lesions the following spring, thus it is safe to conclude, that claw trimming, maintenance and shape correction contribute greatly towards halting the evolution of laminitis related hoof lesions (Manske et al., 2002).

Shearer and Amstel (2001) describe the different methods of claw trimming and the inability of traditional trimming methods to correct hoof overgrowth, which is vital for appropriate weight distribution between the claws. Corrective trimming procedure primary objective consists of adjusting weight bearing, removal of loose horn and removal of hard ridges that may cause further injury to the corium. Corrective trimming procedures are mainly applied in case of horn lesions affecting the claw capsule. Use of a foot block is also a valuable aid, when used on a healthy claw, in order to alleviate weight bearing, when corrective trimming alone is insufficient. Last method to be mentioned is a controversial one, topical treatment. Recommendations on caustic treatment are to avoid such practice and the use of a bandage should be limited to conditions requiring hemostasis. If the bandage removal would take place within 2 to 5 days, that would be acceptable as well.

\section{Hygiene and Footbaths}

According to Ariza et al. (2020), foot dirtiness presents a risk factor for inducing lameness via diseases and is specifically related to an growing prevalence of hock injuries and the occurrence of digital dermatitis (Relun et al., 2013). According to Jacobs et al. (2019) environmental hygiene is tightly related to other infectious diseases as well. These include heel horn erosion, interdigital dermatitis and sole ulcers. A 3 point dirtiness scoring system was devised recently by Ariza et al. (2020). This system scores the lower legs of dairy cows, especially the claws and provides farmers and consultants with a tool both easy to use, and reliable for assessing the dirtiness of cow feet.

Because claw hygiene is identified as a risk factor for claw diseases caused by infection, footbaths can improve claw hygiene and reduce the risk of new infections. Using a footbath is common in the dairy industry for the purpose of control of claw diseases caused by infections. Footbaths are a significant control tool of infectious hoofs, but they are not an equal alternative to proper hygienic practices and treatment and surveillance of lame cows (Cook, 2017).

Footbaths are the most frequent methods for claw diseases control in herds, digital dermatitis especially. Many products are used in different concentrations and densities. Solano et al. (2015) in their study reported that $87 \%$ of 141 freestall farms were using footbaths, with 1 to 4 products. The most frequently used products were formalin and copper sulfate $\left(\mathrm{CuSO}_{4}\right)$. Unfortunately, formalin is carcinogenic (Doane and Sarenbo, 2014) and $\mathrm{CuSO}_{4}$ has negative environmental consequences because of the soil accumulation (Epperson and Midla, 2007).

Smith et al. (2014) presented a more environmentally adequate method. It is a biodegradable solution based on tea tree essential oil and organic acids and can be contemplated as a replacement product. The authors advise the use of a 3\% solution, 5 times a week on a weekly basis.

According to Jacobs et al. (2019) the only foothbath that can significantly reduce the cases of digital dermatitis in dairy cows are the ones with $5 \%$ of $\mathrm{CuSO}_{4}$, applied regulary, 4 times per week. Foothbath has to be done properly in order to be effective, the whole claw has to be covered by a bath solution and the organic matter concentration has to be monitored as well. The footbath has to be optimized for easy flow of cows, while adequate amount of solution are distributed to the cows claws (Ariza et al., 2018). 


\section{Diet and Body Condition}

Diet has an important part in claw health, especially for disorders related to laminitis. Webster (2001) made a comparison between wet diet and dry diet in herd of Holstein primiparous cows. Those fed by wet diet showed increased erosion of the heel and sole, which resulted in an increased claw disease prevalence. The primary cause of laminitis-related claw disease is ruminal acidosis, which results in decreased rumen $\mathrm{pH}$, whoch is typically affiliated with diminishing milk fat percentage. This decline is detectable via the fatto-protein ratio (Schopke et al., 2013). Vlček and Kasarda (2017) evaluated the connection between claw disorders and metabolic status. The of $\mathrm{F} / \mathrm{P}$ ratio effect increased $(\mathrm{P}>0.05)$ sole ulcer occurance by $30.33 \%$ and increased also significantly ( $P>0.05$ ) heel erosion and interdigital dermatitis occurrence by $32.44 \%$ on first lactation and by $47.3 \%$ in summer calving season.

The prevention to avoid ruminal acidosis is achievable by two measures. Firstly, grains have to by supplied in small portions, 3 to 4 times a day, lasting from end of gestation period until post-calving period and secondly, the feed has to comprise of $45 \%$ fodder at minimum (Mongeon, 2003).

Feeding complexed trace minerals (CTM) to heifers during the rearing phase led to increased claw disorders incidence and severity. Conversely, during the same period, claw disease incidence and severity decreased at 2 mo postpartum and helped ease ramifications claw disorders pertain by milk production in the first lactation (Drendel et al., 2005). CTM was provided daily for heifer an additional $360 \mathrm{mg} \mathrm{Zn}, 200 \mathrm{mg} \mathrm{Mn}$ and $125 \mathrm{mg} \mathrm{Cu}$ from amino acid complexes and $12 \mathrm{mg}$ Co from Co glucoheptonate.

Despite the fact that Holstein heifers in study by Webster (2001) didn't show any association between body condition and claw diseases, Sogstad et al. (2007) demonstrated that claw disorders may impact body weight and affect carcass characteristics. These factors bear economic importance at the time of culling (Sogstad et al., 2007).

\section{CONCLUSION}

A review of available literature in the field of claw disorders field points to how serious the negative effect of claw disorders are on cow production and health and how important is to control the situation with using preventive methods and genetic selection to avoid annual costs and neglecting the welfare.

\section{REFERENCES}

AAMAND, G. P. 2006. Data collection and genetic evaluation of health traits in the Nordic countries. In: Proc. British Cattle Breeders Conference. Shrewsbury, UK.

ADAMS, A. E., LOMBARD, J. E., FOSSLER, C. P., ROMÁN-MUÑIZ, I. N. and KOPRAL, C. A. 2017. Associations between housing and management practices and the prevalence of lameness, hock lesions, and thin cows on US dairy operations. Journal of Dairy Science, 100(3): 2119-2136.

ALAWNEH, J. I., LAVEN, R. A. and STEVENSON, M. A. 2012. Interval between detection of lameness by locomotion scoring and treatment for lameness: A survival analysis. The Veterinary Journal, 193(3): 622-625.

ALSAAOD, M., FADUL, M., DEISS, R., BUCHER, E., REHAGE, J., GUCCIONE, J. and STEINER, A. 2019. Use of validated objective methods of locomotion characteristics and weight distribution for evaluating the efficacy of ketoprofen for alleviating pain in cows with limb pathologies. Plos One, 14(11): e0225565.

ALVERGNAS, M., STRABEL, T., RZEWUSKA, K. and SELL-KUBIAK, E. 2019. Claw disorders in dairy cattle: Effects on production, welfare and farm economics with possible prevention methods. Livestock Science, 222: 54-64.

ARIZA, J. M., BAREILLE, N., OBERLE, K. and GUATTEO, R. 2018. Current recommendations for footbath solutions renewal rates in dairy cattle: the need for adaptation? Animal, 13(6): 1319-1325.

ARIZA, J. M., RELUN, A., BAREILLE, N., OBERLE, K. and GUATTEO, R. 2017. Effectiveness of collective treatments in the prevention and treatment of bovine digital dermatitis lesions: a systematic review. Journal of Dairy Science, 100(9): 7401-7418.

BACH, A., DINARÉS, M., DEVANT, M. and CARRÉ, X. 2007. Associations between lameness and production, feeding and milking attendance of Holstein cows milked with an automatic milking system. Journal of Dairy Research, 74(1): 40-46.

BARKEMA, H. W., WESTRIK, J. D., VANKEULEN, K. A. S., SCHUKKEN, Y. H. and BRAND, A. 1994. The effects of lameness on reproductive-performance, milk-production and culling in Dutch dairy farms. Preventive Veterinary Medicine, 20(4): 249-259. 
BELL, N. J. and HUXLEY, J. N. 2009. The use of rubber floor matting on dairy units: a critical review. Cattle Practice, 17(2): 142-147.

BENNETT, G., HICKFORD, J., ZHOU, H., LAPORTE, J. and GIBBS J. 2009. Detection of Fusobacterium necrophorum and Dichelobacter nodosus in lame cattle on dairy farms in New Zealand. Research in Veterinary Science, 87(3): 413-415.

BENZ, B. 2002. Elastische Beläge für Betonspaltenböden in Liegeboxenlaufställen. Ph.D. Thesis. Hohenheim, Germany: Universität Hohenheim.

BOYLE, L., MEE, J. and KIERNAN, P. 2007. The effect of rubber versus concrete passageways in cubicle housing on claw health and reproduction of pluriparous dairy cows. Applied Animal Behaviour Science, 106(1-3): 1-12.

BRUIJNIS, M. R. N., BEERDA, B., HOGEVEEN, H. and STASSEN, E. N. 2011. Assessing the welfare impact of foot disorders in dairy cattle by a modeling approach. Animal, 6(6): 962-970.

BRUIJNIS, M. R. N., HOGEVEEN, H. and STASSEN, E. N. 2013. Measures to improve dairy cow foot health: consequences for farmer income and dairy cow welfare. Animal, 7(1): 167-175.

BRUIJNIS, M. R. N., HOGEVEEN, H. and STASSEN, E. N. 2010. Assessing economic consequences of foot disorders in dairy cattle using a dynamic stochastic simulation model. Journal of Dairy Science, 93(6): 2419-2432.

BURGSTALLER, J., EGGER-DANNER, C., GUGGENBICHLER, S., FÜRST-WALTL, B., STEININGER, F. and KOFLER, J. 2017. The influence of lameness and claw disorders on fertility parameters in Austrian dairy cows. In: Proceedings of the Ninteenth International Symposium and Eleventh International Conference on Lameness in Ruminants. September 06-09, 2017, Munich, Germany, pp. 347-348.

MELENDEZ, P., DONOVAN, A., HERNANDEZ, J., BARTOLOME, J., RISCO, C., A., STAPLES, C. and THATCHER, W. W. 2003. Milk, plasma, and blood urea nitrogen concentrations, dietary protein, and fertility in dairy cattle. Journal of the American Veterinary Medical Association, 223(5): 628-634.

CHARFEDDINE, N. and PÉREZ-CABAL, M. A. 2017. Effect of claw disorders on milk production, fertility, and longevity, and their economic impact in Spanish Holstein cows. Journal of Dairy Science, 100(1): 653-665.

CHESTERTON, R. N. 1989. Examination and control of lameness in dairy herds. New Zealand Veterinary Journal, 37(4): 133-134.

COOK, N. B. 2017. A Review of the Design and Management of Footbaths for Dairy Cattle. Veterinary Clinics of North America: Food Animal Practice, 33(2): 195-225.

COOK, N. B. and NORDLUND, K. V. 2009. The influence of the environment on dairy cow behavior, claw health and herd lameness Dynamics. The Veterinary Journal, 179(3): 360-369.

CRAMER, G., LISSEMORE, K. D., GUARD, C. L., LESLIE, K. E. and KELTON, D. F. 2009. The association between foot lesions and culling risk in Ontario Holstein cows. Journal of Dairy Science, 92(6): 25722579.

CROUÉ, I., MICHENET, A., LECLERC, H. and DUCROCQ, V. 2019. Genomic analysis of claw lesions in Holstein cows: Opportunities for genomic selection, quantitative trait locus detection, and gene identification. Journal of Dairy Science, 102(7): 6306-6318.

DOANE, M. and SARENBO, S. 2014. Exposure of farm laborers and dairy cattle to formaldehyde from footbath use at a dairy farm in New York State. Science of The Total Environment, 487(1): 65-71.

DOLECHECK, K. and BEWLEY, J. 2018. Animal board invited review: Dairy cow lameness expenditures, losses and total cost. Animal, 12(7): 1462-1474.

DRENDEL, T. R., HOFFMAN, P. C., SOCHA, M. T., TOMLINSON, D. J. and WARD, T. L. 2005. Effects of Feeding Zinc, Manganese, and Copper Amino Acid Complexes and CobaltGlucoheptonate to Dairy Replacement Heifers on Claw Disorders. Applied Animal Science, 21(3): 217-224.

EGGER-DANNER, C., FUERST-WALTL, B., OBRITZHAUSER, W., FUERST, C., SCHWARZENBACHER, H., GRASSAUER, B., MAYERHOFER, M. and KOECK, A. 2012. Recording of direct health traits in AustriaExperience report with emphasis on aspects of availability for breeding purposes. Journal of Dairy Science, 95(5): 2765-2777.

EGGER-DANNER, C., OBRITZHAUSER, W., FUERST, C., GRASSAUER, B., ZOTTL, K., FUCHS, K. and FUERST-WALTL, B. 2013. Aspects of validation and data quality based on veterinarian diagnoses. In: Proceedings of the ICAR Conferenceheld. 30-31 May, 2013, Aarhus, Denmark.

EGGER-DANNER, C., NIELSEN, P., FIEDLER, A. et al. 2017. ICAR claw health atlas. In: Proceedings of the International Committee for Animal Recording. 2015, Rome, Italy.

EMANUELSON, U. 2013. Validation of the Nordic disease databases. In: Proceedings of the ICAR Conferenceheld. 30-31 May, 2013, Aarhus, Denmark.

ENDRES, M. I. 2017. The Relationship of Cow Comfort and Flooring to Lameness Disorders in Dairy Cattle. Veterinary Clinics of North America: Food Animal Practice, 33(2): 227-233. 
ENTING, H., KOOIJ, D., DIJKHUIZEN, A. A., HUIRNE, R. B. M. and NOORDHUIZEN-STASSEN, E. N. 1997. Economic losses due to clinical lameness in dairy cattle. Livestock Production Science, 49(3): 259-267.

EPPERSON, B. and MIDLA, L. 2007. Copper sulfate for footbaths - issues and alternatives. In: Proceedings of the Tri-State Dairy Nutrition Conference. 24-25 April 2007, Fort Wayne, Indiana, USA, pp. 51-54.

ESPEJO, L. A., GODDEN, S., HARTMANN, W. L. and WELLS, S. J. 2012. Reduction in incidence of Johne's disease associated with implementation of a disease control program in Minnesota demonstration herds. Journal of Dairy Science, 95(7): 4141-4152.

FABIAN, J., LAVEN, R. A. and WHAY, H. R. 2014. The prevalence of lameness on New Zealand dairy farms: A comparison of farmer estimate and locomotion scoring. The Veterinary Journal, 20(1): 31-38.

FJELDAAS, T., SOGSTAD, A. M. and ØSTERÅS, O. 2006. Claw trimming routines in relation to claw lesions, claw shape and lameness in Norwegian dairy herds housed in tie stalls and free stalls. Preventive Veterinary Medicine, 73(4): 255-271.

GARBARINO, E. J., HERNANDEZ, J. A., SHEARER, J. K., RISCO, C. A. and THATCHER W. W. 2004. Effect of lameness on ovarian activity in postpartum Holstein cows. Journal of Dairy Science, 87(12): 41234131.

GOMEZ, A. and COOK, N. B. 2010. Time budgets of lactating dairy cattle in commercial freestall herds. Journal of Dairy Science, 93(12): 5772-5781.

GONZÁLEZ, L., TOLKAMP, B., COFFEY, M., FERRET, A. and KYRIAZAKIS, I. 2008. Changes in feeding behavior as possible indicators for the automatic monitoring of health disorders in dairy cows. Journal of Dairy Science, 91(3): 1017-1028.

GREEN, L. E., HEDGES, V. J., SCHUKKEN, Y. H., BLOWEY, R. W. and PACKINGTON A. J. 2002. The impact of clinical lameness on the milk yield of dairy cows. Journal of Dairy Science, 85(9): 2250-2256.

GREEN, L. E., HUXLEY, J. N., BANKS, C. and GREEN, M. J. 2014. Temporal associations between low body condition, lameness and milk yield in a UK dairy herd. Preventive Veterinary Medicine, 113(1): 63-71.

GREENOUGH, P. R., WEAVER, A. D., BROOM, D. M., ESSLEMONT, R. J. and GALINDO F. A. 1997. Basic Concepts of Bovine Lameness. Philadelphia, PA: W. B. Saunders.

GUDAJ, R., BRYDL, E., POSTA, J. and KOMLOSI, I. 2012. Effect of lameness on milk production in Holstein-Friesian farms in Hungary. Allattenyesztes Takarmanyozas, 61(2): 66-77.

HASKELL, M. J., RENNIE, L. J., BOWELL, V. A., BELL, M. J. and LAWRENCE, A. B. 2006. Housing system, milk production, and zero-grazing effects on lameness and leg injury in dairy cows. Journal of Dairy Science, 89(11): 4259-4266.

HÄGGMAN, J., JUGA, J., SILANPÄÄ, M. J. and THOMPSON, R. 2013. Genetic parameters for claw health and feet and leg conformation traits in Finnish Ayrshire cows. Journal of Animal Breeding and Genetics, 130(2): 89-97.

HERINGSTAD, B. and ØSTERÅS, O. 2013. More than 30 years of health recording in Norway. In: Proceedings of the ICAR Conferenceheld. 30-31 May, 2013, Aarhus, Denmark.

HERINGSTAD, B., EGGER-DANNER, C., CHARFEDDINE, N. et al. 2018. Invited review: Genetics and claw health: Opportunities to enhance claw health by genetic selection. Journal of Dairy Science, 101(6): 4801-4821.

HERNANDEZ, J., SHEARER, J. K. and WEBB, D. W. 2002. Effect of lameness on milk yield in dairy cows. Journal of the American Veterinary Medical Association, 220(5): 640-644.

HERNANDEZ-MENDO, O., VON KEYSERLINGK, M. A., VEIRA, D. M. and WEARY, D. M. 2007. Effects of pasture on lameness in dairy cows. Journal of Dairy Science, 90(3): 1209-1214.

HORSEMAN, S. V., ROE, E. J., HUXLEY, J. N., BELL, N. J., MASON, C. S. and WHAY, H. R. 2014. The use of in-depth interviews to understand the process of treating lame dairy cows from the farmers' perspective. Animal Welfare, 23(2): 157-165.

HULSEN, J. 2011. Hoof Signals: Success Factors For Healthy Hooves. Zutphen: Roodbont Publishers.

HUXLEY, J. N. 2013. Impact of lameness and claw lesions in cows on health and production. Livestock Science, 156(1-3): 64-70.

CHA, E., HERTL, J. A., BAR, D. and GRÖHN, Y. T. 2010. The cost of different types of lameness in dairy cows calculated by dynamic programming. Preventive Veterinary Medicine, 97(1):1-8.

JACOBS, C., BENINGER, C., HAZLEWOOD, G. S., ORSEL, K. and BARKEMA, H. W. 2019. Effect of footbath protocols for prevention and treatment of digital dermatitis in dairy cattle: a systematic review and network meta-analysis. Preventive Veterinary Medicine, 164(1): 56-71.

KNAPPE-POINDECKER, M., GILHUUS, M., JENSEN, T. K., KLITGAARD, K., LARSSEN, R. B. and FJELDAAS, T. 2013. Interdigital dermatitis, heel horn erosion, and digital dermatitis in 14 Norwegian dairy herds. Journal of Dairy Science, 96(12): 7617-7629.

KÖCK, A., FUERST-WALTL, B., KOFLER, J., BURGSTALLER, J., STEININGER, F. and EGGER- DANNER, C. 2018. Lameness scoring for genetic improvement of claw health based on data from the Efficient Cow project. In: Proceedings of the EAAP Annual Meeting, 2018. Dubrovnik, Croatia. 
KOENIG, S., SHARIFI, A. R., WENTROT, H., LANDMANN, D., EISE, M. and SIMIANER, H. 2005. Genetic parameters of claw and foot disorders estimated with logistic models. Journal of Dairy Science, 88(9): 3316-3325.

KOFLER, J., PESENHOFER, R., LANDL, G., SOMMERFELD-STUR, I. and PEHAM, C. 2013. Langzeitkontrolle der Klauengesundheit von Milchkühen in 15 Herden mithilfe des Klauenmanagers und digitaler Kennzahlen. Tierarztl Prax Ausg G Grosstiere Nutztiere, 41(01): 31-44.

KOFLER, J. 2013. Computerised claw trimming database programs as the basis for monitoring hoof health in dairy herds. The Veterinary Journal, 198(2): 358-361.

KREBS, N., BERRY, S. L. and TUCKER, C. B. 2011. Restless behavior increases over time, but not with compressibility of the flooring surface, during forced standing at the feed bunk. Journal of Dairy Science, 94(1): 97-105.

KREMER, P. V., NUESKE, S., SCHOLZ, A. M. and FOERSTER, M. 2007. Comparison of claw health and milk yield in dairy cows on elastic or concrete flooring. Journal of Dairy Science, 90(10): 4603-4611.

LEACH, A., TISDALL, D. A., BELL, N. J., MAIN, D. C. J. and GREEN, L. E. 2012. The effects of early treatment for hindlimb lameness in dairy cows on four commercial UK farms. The Veterinary Journal, 193(3): 626-632.

MACHADO, V. S., CAIXETA, L. S., MCART, J. A. A. and BICALHO, R. C. 2010. The effect of claw horn disruption lesions and body condition score at dry-off on survivability, reproductive performance, and milk production in the subsequent lactation. Journal of Dairy Science, 93(9): 4071-4078.

MALTECCA, C., PARKER GADDIS, K. L., CLAY, J. and COLE, J. B. 2013. Challenges and opportunities for farmer-recorded data in health and welfare selection. In: Proceedings of the ICAR Conferenceheld. 30-31 May, 2013. Aarhus, Denmark.

MANSKE, T., HULTGREN, J. and BERGSTEN, C. 2002. The effect of claw trimming on the hoof health of Swedish dairy cattle. Preventive Veterinary Medicine, 54(2): 113-129.

MCCONNEL, C. S., LOMBARD, J. E., WAGNER, B. A. and GARRY, F. B. 2008. Evaluation of Factors Associated with Increased Dairy Cow Mortality on United States Dairy Operations. Journal of Dairy Science, 91(4): 1423-1432.

MCINERNEY, J., HOWE, K. and SCHEPERS, J. 1992. A framework for the economic analysis of disease in farm livestock. Preventive Veterinary Medicine, 13(2): 137-154.

MELENDEZ, P., DONOVAN, A., HERNANDEZ, J., BARTOLOME, J., RISCO, C. A. STAPLES and MONGEON, M. S. 2020. Du rumen aux onglons - acidose et laminite. Ministry of Agriculture, Food and Rural Affairs. [Online]. Available at: http://www.omafra.gov.on.ca/french/livestock/dairy/facts/info_feet. htm [Accessed: 2021, May 15].

MOORE, L. J., WOODWARD, M. J. and GROGONO-THOMAS, R. 2005. The occurrence of treponemes in contagious ovine digital dermatitis and the characterisation of associated Dichelobacter nodosus. Veterinary Microbiology, 111(3-4): 199-209.

MÜLLING, C. K. W., GREEN, L., BARKER, Z., SCAIFE, J., AMORY, J. and SPEIJERS, M. 2006. Risks factors associated with foot lameness in dairy cattle and a suggested approach for lameness reduction. In: XXIV World Buiatrics Congres. Nice.

O'CALLAGHAN, K.: Lameness and associated pain in cattle - Challenging traditional perceptions. In: OLMOS, G., BOYLE, L., HANLON, A., PATTON, J. and MEE, J. F. 2009. Hoof disorders, locomotion ability and lying times of cubicle-housed compared to pasture-based dairy cows. Livestock Science, 125(2-3): 199-207.

ØSTERÅS, O., SOLBU, H., REFSDAL, A. O., ROALKVAM, T., FILSETH, O. and MINSAAS, A. 2007. Results and evaluation of thirty years of health recordings in the Norwegian dairy cattle population. Journal of Dairy Science, 90(9): 4483-4497.

PAHLKE, M. 2004. Klauenraspel Gussasphalt. DLZ (Agrarmagazin), 1: 86-89.

RELUN, A., LEHEBEL, A., CHESNIN, A., GUATTEO, R. and BAREILLE, N. 2013. Association between digital dermatitis lesions and test-day milk yield of Holstein cows from 41 French dairy farms. Journal of Dairy Science, 96(4): 2190-2200.

SADIQ, M. B., RAMANOON, S., SHAIK MOSSADEQ, W., MANSOR, R. and SYED HUSSAIN, S. 2019. Dairy farmers' perceptions of and actions in relation to lameness management. Animals, 9(5): 270.

SHEARER, J. K. and VAN AMSTEL, S. R. 2001. Functional and Corrective Claw Trimming. Veterinary Clinics of North America: Food Animal Practice, 17(1): 53-72.

SCHLAGETER-TELLO, A., BOKKERS, E. A. M., KOERKAMP, P. W. G. G., VAN HERTEM, T., VIAZZI, S., ROMANINI, C. E. B., HALACHMI, I., BAHR, C., BERCKMANS, D. and LOKHORST, K. 2014. Manual and automatic locomotion scoring systems in dairy cows: A review. Preventive Veterinary Medicine, 116(1-2): 12-25.

SCHNEIDER, J. H. 2006. Gussasphalt: Immer mehr Probleme. Top Agrar, 2: 28-30. 
SCHÖPKE, K., WEIDLING, S., PIJL, R. and SWALVE, H. H. 2013. Relationships between bovine hoof disorders, body condition traits, and test-day yields. Journal of Dairy Science, 96(1): 679-689.

SMITH, A. C., WOOD, C. L. and MCQUERRY, K. J. 2014. Effect of a tea tree oil and organic acid footbath solution on digital dermatitis in dairy cows. Journal of Dairy Science, 97(4): 2498-2501.

SOGSTAD, M., OSTERAS, O., FJELDAAS, T. and NAFSTAD, O. 2007. Bovine claw and limb disorders related to culling and carcass characteristics. Journal of Dairy Science, 90(2): 749-759.

SOLANO, L., BARKEMA, H. W., PAJOR, E. A., MASON, S., LEBLANC, S. J., ZAFFINO HEYERHOFF J. C., NASH, C. G. R., HALEY, D. B., VASSEUR, E., PELLERIN, D., RUSHEN, J., DE PASSILLÉ, A. M. and ORSEL, K. 2015. Prevalence of lameness and associated risk factors in Canadian Holstein-Friesian cows housed in freestall barns. Journal of Dairy Science, 98(10): 6978-6991.

SOMERS, J. G. C. J., FRANKENA, K., NOORDHUIZEN-STASSEN, E. N. and METZ, J. H. M. 2003. Prevalence of claw disorders in Dutch dairy cows exposed to several floor systems. Journal of Dairy Science, 86(6): 2082-2093.

SOOD, P. and NANDA, A. S. 2006. Effect of lameness on estrous behavior in crossbred cows. Theriogenology, 66(5): 1375-1380.

STEININGER, F., FUERST-WALTL, B., PFEIFFER, C., FUERST, C., SCHWARZENBACHER, H. and EGGERDANNER, C. 2012. Participatory development of breeding goals in Austrian dairy cattle. Acta agriculturae Slovenica, 100(3): 143-147.

TADICH, N., FLOR, E. and GREEN, L. 2010. Associations between hoof lesions and locomotion score in 1098 unsound dairy cows. The Veterinary Journal, 184(1): 60-65.

THYSEN, I. 1987. Foot and leg disorders in dairy cattle in different housing systems. In: WIERENGA, H. J. and PETERSE, D. J. (Eds.). Cattle Housing Systems, Lameness and Behaviour. Dordrecht, The Netherlands: Martinus Nijhoff Publishers, pp. 166-178.

VAN DER LINDE, C., DE JONG, G., KOENEN, E. P. C. and EDING, H. 2010. Claw health index for Dutch dairy cattle based on claw trimming and conformation data. Journal of Dairy Science, 93(10): 4883-4891.

VAN DER SPEK, D., VAN ARENDONK, J. A. M., VALLÉE, A. A. and BOVENHUIS, H. 2013. Genetic parameters for claw disorders and the effect of preselecting cows for trimming. Journal of Dairy Science, 96(9): 6070-6078.

VAN DER SPEK, D. 2015. Genetic Background of Claw Health in Dairy Cattle. Wageningen University.

VAN DER TOL, P. P. J., VAN DER BEEK, S. S., METZ, J. H. M., NOORDHUIZEN-STASSEN, E. N., BACK, W., BRAAM, C. R. and WEIJS A. W. 2002. The pressure distribution under the bovine claw during square standing on a flat substrate. Journal of Dairy Science, 85(6): 1476-1481.

VAN DER WAAIJ, E. H., HOLZHAUER, M., ELLEN, E., KAMPHUIS, C. and DE JONG, G. 2005. Genetic parameters for claw disorders in Dutch dairy cattle and correlations with conformation traits. Journal of Dairy Science, 88(10): 3672-3678.

VAN NUFFEL, A., ZWERTVAEGHER, I., PLUYM, L., VAN WEYENBERG, S., THORUP, V. M., PASTELL, M., SONCK, B. and SAEYS, W. 2015. Lameness detection in dairy cows: Part 1. How to distinguish between non-lame and lame cows based on differences in locomotion or behavior. Animals (Basel), 5(3): 838-860.

VAN PELT, M. L. 2015. Implementation of a claw health index in The Netherlands. In: Seminar des Ausschusses für Genetik der ZAR. Salzburg, Austria, pp. 55-62.

VANEGAS, J., OVERTON, M., BERRY, S. L. and SISCHO, W. M. 2006. Effect of rubber flooring on claw health in lactating dairy cows housed in free-stall barns. Journal of Dairy Science, 89(11): 42514258.

VERHOEF, G. G. M. 2014. Economic impact of foot disorders in dairy cattle. Dissertation Thesis. Faculty of Veterinary Medicine, Universität Utrecht.

VLČEK, M. and KASARDA, R. 2017. Metabolic status related to claw disorders. Acta fytotechnica et zootechnica, 20(1): 6-9.

WALKER, S. L., SMITH, R. F., JONES, D. N., ROUTLY, J. E., MORRIS, M. J. and DOBSON, H. 2010. The effect of a chronic stressor, lameness, on detailed sexual behaviour and hormonal profiles in milk and plasma of dairy cattle. Reproduction in Domestic Animals, 45(1): 109-117.

WALKER, S., SMITH, R., JONES, D., ROUTLY, J. and DOBSON, H. 2008. Chronic stress, hormone profiles and estrus intensity in dairy cattle. Hormones and Behavior, 53(3): 493-501.

WARD, W. R. 2009. Why is lameness in dairy cows so intractable? The Veterinary Journal, 180(2): 139140.

WEBB, N. G. and NILSSON, C. 1983. Flooring and injury - an overview. In: BAXTER, S. H., BAXTER, M. R. and MACCORMACK, J. A. D. (Eds.). Farm Animal Housing and Welfare. The Hague: Martinus Nijhoff, pp. 226-259.

WEBSTER, A. J. F. 2001. Effects of housing and two forage diets on the development of claw horn lesions in dairy cows at first calving and in first lactation. The Veterinary Journal, 162(1): 56-65. 
Contact information

Petra Neirurerová: xneirurerova@uniag.sk (corresponding author) Peter Strapák: peter.strapak@uniag.sk

Eva Strapáková: eva.strapakova@uniag.sk

Peter Juhás: peter.juhas@uniag.sk

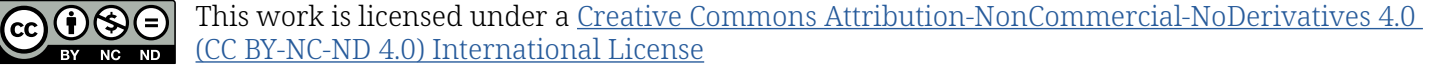

